\title{
Malpractice of Election and General Election Success in 2019 Bali Province
}

\author{
1. I Nyoman Amerthayasa \\ 2. Prof. V. Dr. Rudy Handoko, MS \\ 3. Dr. Ni Putu Tirka Widanti, SS., MM \\ Study Program of Public Administration, Faculty Administration \\ Faculty of Social Science and Political Science \\ University of August 17, 1945 Surabaya
}

\begin{abstract}
Throughout the implementation of elections there are always problems in the process, both of which carry out election malpractice actions, as well as other actions that threaten the general public in voting. The public is not yet fully aware of election activities and their impact. Electoral malpractice reduces the value of democratic elections. This research intends to explain how big the mistakes and cheats that exist during the election took place and how the role of the community to deal with election malpractice. This research uses descriptive analytic method with a qualitative approach. The data used in this study are primary data and secondary data. This research found two types of malpractice: first, people are not very aware of the types of electoral fraud. Both in terms of alleged money politics, campaigns outside the schedule, mounting banners that were considered negative and provocative. Second, the public still does not know that they have entered the voter list, so that there are voters who do not exercise their voting rights, there are voters who use other people's voting rights, and most voters do not know their choice will increase the percentage of voter participation.
\end{abstract}

Keywords: community role, election malpractice, handling malpractice, election success

DOI: $10.7176 /$ PPAR/11-2-04

Publication date:March $31^{\text {st }} 2021$

\section{Introduction}

General Elections (Elections) simultaneously 2019 is just a matter of time, the KPU as the organizer of the election has determined the date of the election which falls on Wednesday, April 17, 2019. This simultaneous election will be very attention-grabbing because, not only electing members of the council who will sit in parliament but also elects the President and Vice President who exercise their authority for 5 years.

One of the functions of the general election is a means of converting the people's voice and the realization of people's sovereignty to produce a government based on Pancasila and the 1945 Constitution. In the 1945 Constitution in Article 1 paragraph (2) states that "sovereignty is in the hands of the people and is carried out according to the Basic Law"

The simultaneous general election will later attract the attention of the public, and it is likely that there will be a significant increase in community participation.

In every election, both the Legislative Election, the Election of President and Vice President, the Election of Regional Heads and Deputy Regional Heads, are inseparable from various forms of violations. Violations in elections are called election malpractice. Malpractice is an obstacle in all stages of the election, both before the election takes place, and during the election.

Independent institutions that have been created by the government are the General Election Commission (KPU), BAWASLU and DKPP. The three institutions are important to be neutral in the holding of elections. In Article 1 Paragraph 7 of Law No. 7 of 2017 reads that "Election Organizer is an institution that organizes elections consisting of the General Election Commission, Election Supervisory Board, and the Election Organizer Honorary Board as a single unit of election management function, to elect Members of the House of Representatives, Members of the Regional Representative Council, the President and Vice President and to elect members of the Regional People's Representative Council directly by the people. "

The article clearly states that the implementation and implementation of elections is not the sole responsibility of the KPU. Bawaslu who plays a role in supervision must also be responsible for all stages of the election. With the KPU's new jargon which is currently titled "Serving", and Bawaslu with the title Oversee, have enthusiasm for the success of holding simultaneous elections in the future.

KPU and BAWASLU play a role in handling election malpractice. Judging from the various violations / malpractices can be described as follows:

1.There were 409 cases in Aceh Province in 2014. There are 220 election criminal cases which include: 7 cases in court, 2 cases have been SP3, 18 cases in the Police, and 193 cases have stopped in Panwaslu. However, for these 193 cases, after being examined it was not included in the election 
criminal case. In addition to criminal election cases, in Aceh there were also 23 cases of violations of the code of ethics. ( http ; // Banda Aceh Post.com, 13 May 2014).

2. Cases in the Province of Bali also occurred when the simultaneous local election took place, including: (i) the use of Paslon attributes (pairs of candidates) carried out by the bureaucratic apparatus; (ii) The number of campaigns before their time. This indicates that malpractice in Bali is largely resolved at the Provincial Bawaslu level. (http://balitribunenews.com August 8, 2017)

3.In East Java Province, malpractice occurred during the simultaneous local elections in 2015. There were 117 violations, including: (i) 64 cases were stopped because there were no proven violations; (ii) While there were 53 cases of proven violations, with details 36 cases resolved at Panwaslu level, 4 cases at the regional level related to the code of ethics, 13 cases were resolved at the Provincial Bawaslu level. The types, mostly related to administration, among others (DPT, APK installation, and civil servants involved in the paslon campaign). Code of ethics violations also occur in Sidoarjo KPU, Blitar City KPU, Lamwas Panwaslu (https://www.merdeka.com, 17 November 2017).

4. In West Java Province there were 37 violations during the 2017 General Election and occurred in 3 Regencies / Cities: Tasikmalaya City 10 violations, Bekasi City 17 violations, and Cimahi City there were 10 violations. Types of violations that occurred in West Java Province, out of 37 cases, included 28 criminal violations, 7 administrative violations, 2 violations of the code of ethics. Criminal offenses, all of which cannot be proven, because many are not proven. Other forms of violations namely, the existence of fake voters (Ghost Voter). False voters occurred during the elections in 2015. False voters occurred in the Muna Regency, Sulawesi. According to Law No.12 of 2008, article 115 double voters or people who use fake identities are threatened with imprisonment. ( http : // www. Antarajabar.com, Friday 17 February 2017).

\section{Research Methods}

This type of research used in this research is descriptive research, which uses a qualitative observation approach. According to Nawawi (2003), the descriptive research method has two main characteristics, first focusing on the problems that existed at the time the research was conducted up to (now) or actual problems. Second, it describes the facts about the problem being investigated as they are accompanied by rational interpretations.

There are 2 (two) types of data used in this study, namely primary data and secondary data. Primary data consist of interviews with KPPS, voters, KPU members related to election malpractice and in-depth interviews with the successful team as perpetrators of election malpractice. Secondary data consists of several other supporting data such as a list of violations and types of violations that occur. The researcher interviewed the officers of the Voters Organizing Group (KPPS). In addition, document review and election regulations were also used in this study.

\section{Theory Perspectives}

In the principles used, the election organizers (KPU and Bawaslu), that the existence of programs and activities in the election stage must have legal provisions and electoral perspectives. With this, the principles of democratic elections also apply to all activities of the election, the election both national and local elections.

Democratic elections are elections that are formed and held based on the provisions and wishes of the people. The will of the people must be carried out periodically and also be carried out based on general and equal principles (universal and equal suffrage). According to Ramlan Surbakti (2017) democratic elections (Pilkada) will give birth to a legitimate government, and the strength of the law and a legitimate government will produce an effective government, capable of carrying out the needs of its people.

There are several principles of democratic elections. The reference in the implementation of the election is First, democratic elections meet the principles of free and fair election. Second, elections with integrity (electoral integrity) state that the parameters of democratic elections must meet the elements of Electoral Justice (legal provisions). That is, the election fulfills the elements of integrity, participation, a definite legal framework, impartial and fair, professional, free, transparent, timely, non-violent, sustainable and acceptable. Third, the principle of the next election must have integrity (Electoral Integrity).

Surbakti (2017) offers 8 (eight) parameters of democratic elections, namely:

1. Election Law and Legal Certainty, Law becomes an indicator of democratic elections, wherein, all procedures for conducting elections must be in accordance with the law and there is legal certainty, aspects of the election are completely regulated (without a legal vacuum), all provisions are consistent with each other (without any contradiction), all provisions are clearly formulated with a single meaning (without the existence of multiple interpretations), and legal provisions must be implemented in practice.

2. Arrangement of all stages of the election implementation process that not only guarantees legal certainty but is also based on democratic election principles, namely direct, general, free, confidential, honest and fair, transparent, accountable, and with integrity. 
3. Equality between citizens, Indicator to see equality of citizens in three parts, namely: (i) Permanent Voter List which includes a high degree in terms of coverage, namely the number of citizens entitled to vote who have been registered in the DPT (Permanent Voter List). (ii) Updates, namely the number of citizens present on polling day entitled to vote, registered in the DPT, the number of citizens who are not allowed to vote and must be excluded from the DPT such as the TNI / POLRI, and died. (iii) Data Accuracy, namely the number of citizens who are not entitled to vote and have been issued in the DPT, and the number of voters whose names and identities have been written as they should, and the principle of equality: what is called OPOVOV (one person, one vote, one value) as well must be guaranteed, where in the process of voting every legitimate vote is counted, and counted equally.

4. Competition between parties or candidates takes place free and fair (Free and Fair Contestation) Competition between parties and candidates takes place in equality.

5. Election organizing which is not only professional but must act independently and impartially in carrying out its duties and authorities.

6. The process of public consultation, tabulation and announcement of the results of vote counting are carried out directly, publicly, freely, confidentially, honestly and fairly, transparently and accountably.

7. The law enforcement system that regulates elections (electoral dispute resolution) is carried out fairly and on time.

8. Community participation in the process of holding elections.

\section{Results and Discussion}

The success of the election can be seen from the role of the community. This means that the community is one of the parameters for the success of the election. The level of participation influences the votes of the voters and determines the victory of one paslon.

Voters have certain voting rights and this right is used properly and correctly and responsibly. Surbakti stressed the importance of upholding the principle of one person, one vote, and equal value (One Person, One Vote and One Value / OPOVOV). This opinion provides a pressure point for equality in the voting and counting process where one vote is judged the same and valid votes are counted equally.

Elections are declared democratic elections if they are carried out freely and fairly. In accordance with the principles of elections, the benchmarks of democratic elections have the principles of: direct, general, free, secret, honest, fair, confidential, and the last is periodic. The meaning of these principles namely;

First , the principle of direct means that voters who have the right to vote can directly vote as voters. And the right to vote is guaranteed by the Law.

Second , the general principle, to be the principle of democratic elections, this is based on provisions that have been agreed internationally, through the Declaration of Human Rights, where in the declaration that the voting provisions are Universal Suffarge, voting must not be allowed to vote because all citizens who have suffrage, whatever the sex, whatever nationality and education, still have the right to vote.

Third , the principle of free, this principle is often a question that "free" as what is meant in the principle, the understanding that voters who have the right to determine their choice, can vote in elections without any pressure or coercion from any party. But in fact there are still voters who voluntarily sell their votes to certain parties, which results in no more freedom of voice because the vote can be bought and there is a vote buying.

Fourth , the principle of honesty, this principle is unique because it discusses something that is still abstract, where the value of honesty is a key to the success of elections and the legitimacy of elections. The principle of honesty is important because honesty will produce integrity in elections. The parts of election integrity, namely: Honest, accurate, there is accountability, transparent.

Fifth, the principle of secrecy, is the principle where every choice chosen becomes a confidentiality that must be maintained in the election process. With a term commonly called "Don't Ask and Don't Tell", it states that each choice does not need to be asked and does not need to be explained, because the choice of votes is confidential, so that the public does not know about our choices.

Sixth, the principle of fairness, in this election principle, a sense of fairness is an action taken by voters, and election participants, by the organizer during the election implementation process. The reality of the election implementation still shows the deliberate mistakes of the community, both those made by the election organizer and the election participants and the voters themselves. Examples of still buying and selling votes (vote buying). Buying and selling results in a loss of fairness in the election. The principle of fairness is a principle that must be implemented by all parties.

Seventh , the periodic principle is the principle of the last election because elections must indeed be held every 5 years, the aim is to evaluate the performance of the elected representatives of the past period and re-elect for the government, whether the previous government was still eligible to run the wheels of government.

Voter participation has always been a benchmark of election success, with a variety of varying percentages. If we look back at the 2017 Governor and Deputy Governor Election, which was enough to attract public 
attention, the voter percentage was no more than $75 \%$, which means that the level of voter participation was also not very significant.

From the forms of participation in choosing citizens, there are more or less nine (9) forms of participation including:

1. The involvement of political parties as election participants in the process of selecting candidates for members of the DPR and DPRD, in providing input for the formulation of the vision, mission and program of political parties that will be implemented in the election. This means that political parties also play a role in delivering the vision, mission of the party to the lowest level. But apparently very few political parties have taken this action to the grassroots.

2. The involvement of activists of Election (coming from NGOs) to be me ny eleng ga ra ka np ro $\mathrm{g}$ ra $\mathrm{m}$ education vote (voters education).

3. Actively supporting election participants, being able to become active and good campaign participants, which means that election participants, in this case political parties, must of course prioritize honesty and responsibility and offer visions, missions that are in line with the needs of the community. Can be seen lately, people have almost lost confidence in political parties. Political parties do not conduct vote buying. Because this action is very contrary to the Luber and Jurdil Principle (Direct, General, Free, Secret, Honest and Fair).

4. Existence, election monitoring institutions involved in the electoral process, in accordance with Law No. 7 of 2017, Election Oversight is held and registered with Bawaslu. In accordance with article 351 paragraph 6 of Law No. 7 of 2017 stating that "Voting Monitoring is carried out by Election Observers who have been accredited by Bawaslu, Provincial Bawaslu and Regency / City Bawaslu"

5. Many people are aware of violations before the election guarantee, but most people do not want to report the form of violations. The involvement of voters in reporting alleged violations of the election must of course be given appreciation and support that voter actions in reporting election violations can be protected by law. Election law has regulated voters and determined parties who could report suspected election violations including: registered voters, election observers and election participants. Various allegations of violations can be reported to the Election Supervisory Body (Election Supervisory Board / staff at the lower level of the Election Supervisory Body, including Regency Bawaslu and District Supervisory Committee.

6. The next participation was that voters came to the polling station to vote or vote on D-Day (voting day). When viewed from the Sidalih data ( voter data system ) for the number of registered voters on an ongoing basis, to date there are approximately 279 million people.

7. Furthermore, to find out the form of participation, namely through the involvement in survey institutions where the agency carries out surveys of election participants, voters, election organizers, and election observers and disseminates information on results to the general public. From these institutions include:

a. Exit Poll as a surveying institution that surveys random voters in various polling stations.

b. Barometer Indonesia as a quick count survey institution.

c. Kompas Polling as a quick and random count survey in TPS during the simultaneous local elections of the 2017 Governor and Deputy Governor of DKI Jakarta.

8. Media involvement in politics, where the media is actively involved in the process of covering election activities, and / or disseminating information related to elections.

9. M en gene a ipa RTI sipasidap at is done by following the counting process conducted at polling stations, and then disseminate information on the results from the polling stations. This can also be a voter control over their choices at polling stations.

The public is said to have awareness of their rights as voters, if the organizer presents information related to the election and the rules that exist and must be implemented. However, the availability of information related to the voter list is not yet known by the public so the public does not give their voting rights. The implication of this is that the community becomes passive and silent so that the election fraud is unknown to the public. This research can also show that there is also vote buying. Voting is done by a successful team participating in the election, and selling the vote is done by the voter. Voters do not know this and this is part of violations / malpractice elections. Vote buying does not occur if voters refuse to sell their votes.

Voters as the owner of the absolute voting rights have responsibility for what will be voiced. Of course, every voter registered in this country must be able to trace the entire process in the stages of the election implementation which include :

1. Familiarize himself with the candidate, and know the background (track record) or career path of the candidate, as well as the issues that are present in the candidate.

2. No change of address, when registering voters, if moving should take care of the administration which is already a procedure in the population and civil registry services, so that data is revoked. 
3. Know the location of polling stations and the time the ballot began. Knowing the location of the TPS becomes important in order to facilitate the voting rights. And in order to keep getting sound according to the place where it is placed.

4. Bring personal identity when heading to the polling station.

5. Familiarize yourself with the items and equipment at the polling station.

6. Giving the right to vote on the ballot correctly, namely by voting on the sign, the name of the candidate pair (pilkada) or (presidential election), or the name of the candidate legislative member.

Election fraud occurs because voters still lack knowledge about electoral. In this case includes: the stages of the election, candidacy, the campaign period and actions that are included in the category of election malpractice. If there are objections from the public over the election results, it is necessary to re-examine whether there is a link between the fraud committed by organizing the election. The results of the study must also attach and have evidence of fraud committed in the election including, among others:

a. The involvement of election organizers in the act of theft of votes. This is usually done by the organizer at the lower level, so that there is a need for control in the supervision of votes when the vote count takes place.

b. Their action over the whole letter sounds are stored in a safe place, and must be guarded by security forces.

c. There is registered voter data but it turns out it is not in accordance with its identity after confirmation and matching data, this results in the existence of false voter data. And there is a possibility that this data can be used by certain parties. For example, the address of an incorrect voter, and the name of the voter listed on the DPT is not the actual person.

This is evidenced from the results of interviews with KPPS officers who were in one of the polling stations.

Election travel simultaneously will affect all elements of society, both in terms of voting behavior of citizens, which can also change and will be difficult to predict, where, when the simultaneous general elections later. Voters can choose 5 ( five ) different choices as examples of predictions:

1. Voters elect DPR RI angora from party A, DPD from party B, Provincial DPRD because their friends are from party C, and Regency / City DPRD because their brothers are from Party D, but for the President and Vice President from those carried by parties B, D, E . 5 choices and 5 different ballots will be very many variations to choose it.

2. Furthermore, voters may elect the President and Vice President who are carried by parties A, B, C, but the choice of the DPR, DPD, Provincial DPRD, Regency / City DPRD from a party that does not choose or does not nominate a candidate pair.

3. However, if the voters really have an ID-Party, then Voters will produce voters who elect the President and Vice President of Party A followed by candidates for DPR members from Party A, DPD, Provincial DPRD, Regency / City DPRD. Voters are consistent over what is chosen based on a party that carries a vision and mission that is in accordance with the conscience of voters.

\section{DPT problems}

Permasal a han DPT ti d ak inexhaustible, to be discussed and questioned, but we all know, that the DPT Elections begin to experience improvements over time. In 2014 during the legislative and presidential and vice presidential elections, voter data used voter data on an online basis and data was accessed through a system called Sidalih. From this voter data system it can be known with certainty, whether or not voters are registered in the DPT, as well as multiple voter data.

Permanent Voter List (DPT), in 2015 out of 41 million more voters, there were around 5 million residents in 101 regions who did not have e-KTPs. For information, in 2015 e-KTP became a requirement for someone to be able to vote. For 2018, the determination of DPT based on domicile will start in March and for the DPT 2019, it will follow the DPT in the previous year. (Kompas, 15 February 2017).

On the same occasion, KPU Commissioner Hadar Nafis Gumay confirmed that it would immediately respond to the DPT problem. Hadar Nafis Gumay also said, anyone who has not been registered in the DPT will not lose their voting rights. The person can go to the polling station where he lives according to ID card, one hour before the election time is closed. "So those who have not been registered can still vote in their respective TPS by bringing their e-KTP or certificate," said Hadar (Kompas, 15 February 2017).

\section{Variety of Malpractice Elections}

Simultaneous elections have a much greater potential for cheating than simultaneous local elections. Because before the voting takes place, and before the voting and must be prevented is when the vote recapitulation process is in the polling station. Seen from the fraud violations in the form of involvement of the village government apparatus in its status as a state civil apparatus (ASN) which is included in the structure of holding elections at the KPPS and PPS levels. This is a form of structured, systematic and massive cheating . 
The following is the potential for fraud in the process of organizing the elections and elections that have taken place from election to election, among others, namely:

1. Money politics, this variant of cheating almost always exists in elections, how can I not because money politics has always been a means, to influence someone in voicing his voice. In this case, of course voters who are not intelligent and willing to act on money politics will side with the money givers or money politics actors. The decision taken by the voter is no longer based on whether or not the candidate will be chosen, rather, the voter will side with the candidate who has given the money. The term money politics refers to the use of money to influence political decisions in elections or in other matters relating to other important decisions.

2. The next malpractice is the inflation of the number of voters listed in the DPT (permanent voter list), where the Mal-Practice can be done by the organizers who deliberately want to inflate the vote. The chaos of the Permanent Voter List (DPT) is increasingly worrying for many parties. The number of Voters listed in the DPT is very potential to be inflated by certain parties in the simultaneous local elections and 2019 elections simultaneously. However, please note that the DPT is generated from the process of updating the data, which is where the data comes from DP4 (Potential Voters List), which is then processed into DPS (Provisional Voter List) then DPS data is updated again through Sidalih, which data is feasible to be set as DPT. In Sidalih, it is known, which voters have double data, are not old enough on election day D, and voters who have not (died) and moved to vote must be deleted in the DPS and not stipulated in the DPT

3. The existence of multiple identities, multiple identities occur because of errors when recording identity change data into an electronic KTP (e-KTP). According to data provided by the Ministry of Home Affairs that the DP4 data, that most of the data in DP4 is still incomplete or there is still data that has a dual population. Disdukcapil also does not dare to just delete existing data . Duplicate data can also be known in the Voter's Data System or Sidalih, because in this system, it can detect voters for example: (i) City A and City B: same name, place of birth date, same sex, different address, model such as this can be ascertained by the double voter data of different regions, then the action that must be taken by the organizer is to record the existence of the person, if there is an area / City A then it must be deleted in City $\mathrm{B}$, and vice versa; (ii). The next double variant is the same name, same place of birth, same sex, same address, so this is certainly double. There are many other dual variants that can be detected via Sidalih. The data provided by the Ministry of Home Affairs should be clean data. This is to facilitate voter data collection.

4. The campaign precedes the schedule, it can be said as one variant of election malpractice. Campaigning prematurely and unbalanced campaigns often happens on purpose, electronic media. As is known, currently so many campaigns are aired on electronic media. The campaign costs to be incurred are of course very large, ranging from vehicle costs for candidates, making posters, brochures, to making other campaign costs in other media.

5. As explained previously, various kinds of actions and fraud will always appear in the stages and implementation of elections, of course this needs to be dealt with together. The community as a bridge in safeguarding democracy, must be able to know and avoid the frauds that exist when the election takes place.

Bawaslu makes every effort to maintain the existing democratic sovereignty, so that the process and implementation of elections can take place properly and democratically. If the role of the community and the Election Supervisory Body can be maintained, of course, it will produce quality and democratic elections. According to Susan Hyde, et al (2008) in her book Election Fraud that there must be a Detecting and Deterring Electoral Manipulation (detecting and avoiding election manipulation). Where the main problem in elections is how to recognize and prevent the indications of Election Fraud (election fraud), election manipulation, or theft of votes quietly, vote rigging (structured) where an election fraud occurs due to intervention or interference illegal hand over the election process.

Fraudulent acts usually emerge and have an impact on the counting of votes which can affect the results of the ongoing elections, both in increasing the voter turnout, reducing the voter turnout, changing the choice even in one party of choice.

Although some studies suggest that electoral fraud is also part of illegal actions that violate the law, election fraud that does not reflect the spirit of democracy in electoral rules is contrary to democratic principles.

Hyde (2008) in his study identified electoral fraud, including: (i) The existence of voter manipulation (demographic manipulation, elimination of voting rights, splitting opposition support); (ii) intimidation; (iii) buying and selling votes against voters from election participants; (iv) misuse of information; (v) manipulation of ballot papers; (vi) double punch; (vii) manipulation in recapitulation; (viii) The use of false voters; (ix) damage the ballot paper; (x) piracy of information technology systems in voting; (xi) piracy prohibition of voting rights; (xii) manipulation of the results of vote recapitulation.

The public can detect and avoid election fraud. This can be handled with a number of actions from the role 
of the community:

1. The community as part of the social community must be able to be aware of the election activities that will take place, both the Legislative Election, the Election of President and Vice President, Pemilukada (General Elections of Regional Heads and Deputy Regional Heads), Election of Governors and Deputy Governors.

2. Voters must know where the polling station where, should provide voting rights, by way of checking in the data Sidalih website (www. Kpu.go.id) District Sidalih Atar place of origin, or come to the village to see the S-DPT (DPT copy).

3. After knowing where the polling station is, make sure you get a notification letter to vote (C6), which until now is still distributed by PPS.

4. Voters come to the polling station, to vote on the date specified. TPS is open from 07.00 to end until 13.00 .

5. Voters came to monitor the election process, until the voting ended. And if the voters are willing, then after the voting is closed, the vote count will be continued.

6 . The vote counting process continued with, opening the ballot boxes one by one, for example the first ballot box opened was the DPR RI ballot box. After being opened and viewed, the ballots are recalculated, whether they are in accordance with the number of voters who came. The principle is that voters who use voting rights are a number of ballots that are in the box. if it is not the same then, it is feared there will be a vote bubble or theft.

7. As an intelligent voter, and remain committed to his choice, can vote freely, and not be intervened by any party, the voter must be consistent with his choice, if the voter sells his vote then it can be categorized as an act of buying and selling votes.

8. After the voting was over, the organizer at the TPS level held a vote recapitulation. This recapitulation, became the main milestone in determining the results of votes at KPPS, recapitulating all the results that had been entered. in this case all members of the KPPS are responsible for the vote recapitulation.

9. Pe $\mathrm{m}$ Invert Selection to participate prose s voting by way of observing and detecting the results of an incoming voice, data was manually recap, noting privately what had happened at the polling stations during the voting took place. If there are irregularities and kecuranga $\mathrm{n}$ P emilih Dapa $\mathrm{t}$ reported in nearby Supervisory Committee.

\section{Conclusions}

Election Violations Occur because of limited voter knowledge. This limited knowledge is the cause of electoral malpractice, and makes elections with no integrity. Elections with no integrity are often used by political parties participating in the election as well as by legislative candidates to commit fraud.

To realize an election with integrity, socialization needs to be related to the variety of election practices. This program can be delivered to the wider community, so that the public knows, detects and prevents and handles malpractice before violations have widespread impacts and occur further in the midst of the community. The results of the election process can also be well-legitimized and can be trusted by the general public.

On this occasion the researcher gave a recommendation: firstly that the election organizers, both the KPU and Bawaslu, would maintain integrity in carrying out their duties. KPU and Bawaslu can work together, work together in the whole process of implementing and handling election malpractice, both before the election takes place, during the election and when updating votes (including vote counting) until the votes of the election results are passed.

If there is a dispute between witnesses of candidate pairs of various parties such as witnesses of candidate pairs, political parties and sympathizers who feel disadvantaged in the voting and vote counting process, they can object to the election supervisors, with strong and correct evidence.

The public should be able to know and understand the processes that exist during the stages of the election, publication and socialization of the election process that is running. The active role of the community in preventing election violations and malpractice will certainly result in democratic elections. Communities that are responsive and active in the conduct of elections must naturally be aware of the variety of violations and prevent violations that can interfere with the implementation of elections, both structured, systematic and massive (TSM) violations.

\section{BIBLIOGRAPHY}

Assiddiqie, Jimly. ( 2013) . Upholding Election Organizer Ethics, Jakarta:Raja Grafindo Persada.

Birch, Sarah ( 2011). Electoral Malpractice: Oxford: Oxford University Press.

Surbakti, Raman et al. (2008). Engineering Election System for Democratic Political Governance, Jakarta: Indonesian Partnership

Surbakti, Ramlan et al (2017). Inauguration Lecture " Election Governance As Applied Election Sub-Study " at 
Airlangga University, Surabaya.

Surbakti, Ramlan et al. (2011). Election Violation Handling, Jakarta :Indonesian Partnership .

Susan, D Hyde et al . ( 2008). Election Fraud: Detecting \& Deterring Electoral Manipulation, Brookings Institution Press.

Helena Catt, Helena, Andrew Ellis, Michael Maley, Alan Wall, and Peter Wolf. (2014).Electoral Management Design, Sweden: International IDEA.

Nawawi, Hadari. (2003) Human Resource Management for Competitive Businesses. Gadjah Mada University Press. Yogyakarta. 